\title{
THE CONCEPT OF EXCESS PROFITS UNDER THE REVENUE ACTS OF 1940-42
}

\author{
CARL Shoup*
}

Congress has developed a concept of excess profits during the past three years, vague on some points but fairly definite on others. It is not expressed in summary form anywhere in the four revenue laws that have initiated and revised the excess profits tax; the present paper is an attempt to distill it out and compare it with concepts designed for peacetime taxation. ${ }^{1}$

Implicit Distinction Between War Profits and Other Profits.-Although the tax law makes no formal distinction between profits due to the war and all other profits, it is evidently intended to reach only the former. The taxpayer is given the option to use either the base-period method or the invested-capital method, whichever results in the smaller tax. ${ }^{2}$ As a consequence, the tax is not imposed on profits on the grounds that they are larger than they need to be to induce the firm to carry on at its existing level of output. If excessive profits in this sense were being received in the base period, they can be received in wartime free of the excess profits tax. Further evidence of the desire to tax only profits that are due to the war lies in the refinement of the base-period concept, discussed below, to approximate the peacetime earning power inherent in the corporation as it stood just before the defense effort of the United States got well under way.

Moreover, even an increase in profits over the level of the base period is exempt if that level was very low in terms of per cent of invested capital. Specifically, the taxpayer's option referred to above means that the law exempts any increase in profits over those of the base period up to the point where the wartime earnings are $5 \%$ (ranging up to $8 \%$ for smaller firms) of invested capital. This provision might reflect

* A.B., 1924, Stanford; Ph.D., 1930, Columbia. Associate Professor of Economics, Columbia University. Acting Assistant Director of Tax Research, Treasury Department. Director of Research, Twenticth Century Fund Survey of Taxation (1937).

The present article is intended to reflect only the author's views.

1 To facilitate this comparison, the order in which the topics are treated follows in general that employed in the author's The Taxation of Excess Profits (1940) 55 Pox. Scr. Q. 535, (1941) 56 id. $84,226$.

An advance tabulation of data from taxable excess profits tax returns for 1941 (i.e., with all or the greater part of the accounting period falling in $194 \mathrm{x}$ ) received in the Bureau of Internal Revenuc from the offices of the collectors through July $3 \mathrm{I}, \mathrm{x} 942$, unaudited, show that the two methods were about cqually popular in terms of number of returns ( 18,760 used the base-period method and 18,337 the investedcapital method); but the aggregate excess profits net income of the taxpayers using the base-period method was $\$ 7.0$ billion, against only $\$ 3.4$ billion of those using the invested-capital method. Treas. Dept., Butz., Sept. 1942, p. 7 r. 
a belief that, even had the United States not become involved in the war, the corporations in question might have improved to the point of earning at least $5 \%$ (to $8 \%$ ) in 1940 and the following years. But a simpler and probably more nearly accurate explanation is that Congress desired to give the depressed industries of the 'thirties, like steel and the railroads, a chance to make a certain minimum amount of profit out of the war, the minimum reflecting something more than was needed to keep them going during the war but perhaps something less than would be required over the very long run in peacetime.

The law makes no attempt to impose a higher tax rate on income from government contracts. Under the present tax, which varies from $72 \%$ to $81 \%$ after post-war refund, there is not much room for an added rate on such income. Renegotiation of contracts is perhaps considered to provide the extra safeguard needed, although in practice it may work the other way around, with renegotiators finding their task made bearable only by the thought that the Government will in almost any case get $72 \%$ to $81 \%$ of what is not renegotiated out. Perhaps the pattern of the last war will be followed, and any reduction in tax rate in the immediate post-war period be disallowed with respect to income from wartime government contracts.

Emphasis on Experience of the Particular Corporation.-The attempt to restrict the excess profits tax to war profits involves treating each taxpayer in the light of its own particular business history and prospects. The invested-capital method does not lend itself readily to this approach; the base-period method does. Congress has shown its preference for the individual-case approach by refining the base-period method and enlarging its scope in successive revenue acts. Indeed, the process of refinement has come close to creating a third, overriding measure for excessive profits, one calling for more individual treatment than even the test of actual experience. This third concept is difficult to define briefly, but it seems to be something like this: excessive profits are those in excess, not of the profit that the firm did earn in the base period, but of the profits that it could have earned in the base period if all through that period there had been fully operative the reasonably assured potentialities that the concern exhibited at the close of the last year of its base period and if the base-period years had been marred by no exceptional or unrepresentative physical or economic misfortunes. Or, as the Senate Finance Committee put it briefly, the excess profits credit based on income will be "predicated upon an amount which is a fair and just reflection of the normal earning capacity of the business."3

The I940 law, with some exceptions, used the actual base-period experience of the taxpayer as a direct measure of what should be a tax-free return in the war years. But under the I942 law, the actual base-period experience will in many cases be not so much a measure as a preliminary indicator, a starting point from which to build up a hypothetical statement of what might have happened to the particular corporation in question under fairly happy business conditions. Most of this building-up takes place under the auspices of Section 722 of the Internal Revenue Code, which was

${ }^{3}$ The Revenue Bill of 1942, SEN. REP. No. I631, 77th Cong,, 2d Sess. (1942) 197. 
radically expanded by the 1942 act. The extent to which Congress is willing to have each case considered separately is indicated by the following illustrations, selected from the report of the Senate Finance Committee and the Treasury Regulations, in which an "excessive and discriminatory" tax could be avoided by a "constructive average base period income" that would be "a fair and just amount representing normal earnings":

Sec. $722(b)(x)$ : "Fires or floods would be events hindering the operations of the business [in the base period]." 4

Sec. $722(b)(2):$ ". . . assume that a corporation for a long period of years conducted business with one customer which, during the base period, it lost because such customer decided to manufacture the product it heretofore bought. The corporation would be compelled to develop a new market ... a corporation which belonged to an industry the members of which were engaged in a price war during several base period years. As a result of sales below cost during those years, the members of the industry sustained losses. ..."

Sec. $722(b)(3)(A)$ : "The machine-tool industry is a possible example of this type of business with a business cycle different from the general business cycle ... retooling orders, furnishing the opportunity for profit, do not necessarily occur with every period of business prosperity."

Sec. $722(b)(3)(B):$ ". . a member of an industry which does not have an earnings experience which can be segregated into definite cycles. ... An industry engaged in the preparation and canning of fruit is a possible example of this class of business."7

Sec. $722(b)(4)$ (change in operation or management): “. . in 1936, a corporation was reorganized and the new directors made drastic changes in the management. . . The effect of the changes in sales and production policies initiated by the new management was not reflected in the company's earnings until r939. . . . In 1936 a company engaged in coal mining converted from a system of hand loading, under which it lost money, to mechanized loading. ... In 1938 a concern which marketed its product from door to door changed such sales methods to direct sales to retailers. As a result, its earnings increased." 8

(a difference in the products or services furnished): ". . . a corporation, which until I934 manufactured snuff at a loss, in that year changed to the manufacture of cigars. Due to normal difficulties in establishing trade connections and in establishing its product, it did not realize normal earnings until $x 938 . " 9$ ".. a corporation in one year of its base period was engaged in both the radio broadcasting business and the department store business and on January $x, 1940$, was engaged only in the radio broadcasting business, the department store business having been discontinued ... a corporation was engaged in one of the base period years in both the wholesale and retail dry goods business and on January I, I940, was engaged only in the retail dry goods business." 10

(a difference in the capacity for production or operation): “. . in r 939 a mining company began the development of a new mine and the construction of a new plant to be used in connection with such mine. . . The mine and the plant were completed and entered production in November 194r.... In determining the amount of the constructive average base period net income, the extent to which the new facilities entered into the business of the corporation for the taxable year shall be considered to be the extent to which the character of the business was changed on December 31, 1939."11

\footnotetext{
'Id. at 198 . The Regulations (Treas. Dec. 5045, May 3, x94I), p. 28, add strikes as another possibility.

${ }^{5}$ SEN. REP. No. I63I, supra note 3, at r99.

Ibid.

${ }^{8}$ Id. at $20 \mathrm{x}$.

${ }^{10}$ Treas. Dec. 5045, May 3, I941, p. 27.

${ }^{7} I d$. at $199-200$.

Id. at 200 .

${ }^{11}$ SEN. Rep. No. 163I, supra note 3 at p. 202.
} 
(a difference in the ratio of non-borrowed capital to total capital): No examples are given.

(acquisition of assets of competitor, diminishing or eliminating competition): ". . two competing newspapers were operating at a loss during all or part of the base period. Prior to January $x$, I940, the first newspaper purchased the franchises and other assets of the second newspaper and as a result of this transaction the condition of the surviving paper was much more promising." 12

(full effect of above changes in business, or commencement of business, not felt by end of base period): “. . . a corporation . . . in 1938 , started a delivery route selling food products such as peanuts, potato chips, and similar products. For 1938 it showed a loss. Its earnings for 1939 increased in each quarter-year period. With a record of steady growth such corporation might be deemed to have commenced business in $1936 . " 13$

(any other factor resulting in an inadequate standard of normal earnings): ". . . assume that a taxpayer was organized in 1935 to distill and sell whisky. It had no reserve whisky stocks on hand. During 1935 and for the greater part of its base period, it was aging the whisky it had distilled. Because of a lack of a marketable product, the sales of such taxpayer, and consequently its base period net income, were abnormally low. ..."14

The actual base-period earnings in each of these cases seems at first sight an obviously inadequate standard. But the inadequacy may be more apparent than real. Perhaps the interruption of production due to a flood merely resulted in a postponement of operations, with a consequent abnormal increase in business later in the base period. Perhaps the loss of the chief customer and the building up of a new market commonly occurs several times in the life of an enterprise in the industry under consideration; if it happens during an excess profits tax taxable year, no hypothetical increase in taxable profits is required. Price wars are "normal," in many industries, if the period in question is long enough. The difficulties of the individual-case approach are indicated by the absence of any definite standards, in the law, for the building up of the constructive, hypothetical base-period income, and by the provision of special administrative machinery to handle the cases. What standards will the Internal Revenue Bureau and the Tax Court follow?

Perhaps they will resort to something that might be called retrospective business cycle forecasting for the individual firm, by starting with its actual profits experience in the one or more years of 1936-1939 that were not affected by the strike, flood, fire, or price war, and by trying to fill in the missing years against the background of general business conditions. Still more imagination will be called for when the concern as it stood at the end of the base period, with its new product, its enlarged production capacity, its improved sales methods, and its rejuvenated management, is projected backward in time and assumed to be operating in an environment otherwise unchanged from what it was in 1936-39-or will account be taken of hypothetical changes in competitors' situations that would have been caused by these improvements?

The hypothetical base-period income might conceivably be arrived at by applying some percentage of fair return to the capital investment as it stood at the end of the

13 Treas. Dec. 5045, p. 27.

${ }^{13}$ SEN. REP. No. r63I, supra note 3, at 201. It Id. at 203. 
base period, but this solution would seem an almost direct negation of Congressional intent. The excess profits tax law as it now stands reveals a strong desire to avoid the use of the invested capital standard if the taxpayer can possibly be relieved in any other way. The extreme instance of this is Section 722 (c) (3), which allows a taxpayer that was not in existence during the base period to build up a purely hypothetical constructive base period income if "the invested capital of the taxpayer is abnormally low." And a taxpayer that was in existence only part of the base period need not fill out the rest of the period by taking $8 \%$ of its invested capital as of the start of its first taxable year (Sec. $7 \mathrm{I}_{3}(\mathrm{~d})(2)$ ) if it can do better by constructing a hypothetical income for the period.

Why has Congress gone so far down the path of individual treatment under unspecified standards, in view of the obvious difficulties? At least three reasons come to mind.

First, an accident of business cycle history blocked one remedy that could be cast in general terms, that is, lengthening the base period and thus lessening the distortion caused by the abnormal events of one or two years, or by the normal absence of a profits cycle synchronizing with that of the "general business cycle" (Sec. 722(b) (3)). Behind 1936 stretched the great business depression of the 'thirties. A split base period, say $1925-29$ plus $1936-39$, would have utilized experience too remote to be dependable. A lengthened base period would not, of course, help the taxpayer whose character of business was changed toward the end of the period.

Second, Congress has probably considered the tax to be a temporary one, imposed for a short war. Hence there is correspondingly smaller chance that abnormalities in the incomes of taxable years will be averaged out. This point concerns more directly Section 72I, which defines "abnormal income" of a taxable year, but it also makes more important (in striving to protect all taxpayers against harsh treatment) the construction of a base period average that is free from unfortunate events that are abnormal for short periods, however normal they may be for long ones. If the excess profits tax were to last for ten or twenty years, there would probably be at least one price war, flood, or fire that would, to some extent, counterbalance the effect of the similar occurrence in the base period. But this point can easily be overemphasized. Even for a long-lived tax, a base period should have in it no more than a fraction of the effect of an unusual event, corresponding in size to the fractional effect in the annual average of profits over the taxable period.

Third, an invested capital standard can be made a general relief provision by giving the option to use it to the taxpayer, not the Government. The present law does give the taxpayer this option, but the percentage applicable to the invested capital has been set fairly low, evidently in order to get at least some excess profits tax from concerns whose booming war business contrasts sharply with a period of stagnation in 1936-39. The resulting excess profits tax credit under the invested capital option, although higher than that obtained by referring to actual base-period experience, may have appeared to Congress lower than what taxpayers with peculiar 
base periods-not mere unrelieved stagnation-might properly hope for. The business world has so much in it of risk on the one hand, and monopolistic elements on the other, that a standard of 5 to $8 \%$ on invested capital probably falls considerably short of both expected and actual earnings of the majority of enterprises in industries that have not passed completely through the expansion phase. If the invested capital credit had been set at, say, $12 \%$, the pressure for special relief provisions would presumably have been much less.

But even these reasons seem not fully to explain the partial disintegration of the base-period law into a series of special cases, especially since the legislators have provided three methods for the taxpayer within the framework of the base period itself. Under one of them, introduced in the Revenue Act of 1942, the credit is equal to $89.061 / 4 \%$ of the average of the income of the three highest income years of the base period. ${ }^{15}$ Taxpayers with year-to-year fluctuations in base-period income so slight that they get a higher average base-period income by simply averaging the income of the four years are permitted, in fact required, to do so. Still others will use the third method, designed particularly for corporations that were expanding in the latter part of the base period; it utilizes a modification of the trend method known to statisticians as the "semi-average" procedure, adding to the average of the last two years one-half the difference in the average of the first two years and the last two (with the highest year's income as a maximum for the final figure). In the advance tabulation of 37,097 excess profits tax taxable returns, this option for "growth" corporations was very popular; of the 18,760 returns filed on the income method, 9,707-52\%-used it. ${ }^{16}$ At that time, however, the general average method was somewhat less favorably defined for the taxpayer than it is under the $75 \%$ provision noted in footnote 15 and the relative popularity of the "growth" method may decline somewhat.

In the light of these options, the chief significance of the constructive base period is the tendency it reflects to atomize the law, which presumably should instead be fairly general. It might be instructive to count the number of clauses already in the income tax ${ }^{17}$ and excess profits tax laws designed in the first instance to care only for

${ }^{15}$ The law says, "If the excess profits net income (or deficit in excess profits net income) for one taxable year in the base period divided by the number of months in such taxable year is less than 75 per centum of the aggregate of the excess profits net income (reduced by deficits in excess profits net income) for the other taxable years in the taxpayer's base period divided by the number of months in such other taxable years (herein called "average monthly amount") the amount used for such one year under this paragraph shall be 75 per centum of the average monthly amount multiplied by the number of months in such one year, and the year increased under this sentence shall be the year the increase in which will produce the highest average base period net income. ..." $\$ 7 I_{3}(\mathrm{e})(\mathrm{I})$. Hence the average base period excess profits net income cannot fall below the average of (a) the three highest years and (b) one year presumed to have an income $75 \%$ of that shown by (a). If (a) is roo, the result is

$$
\frac{(100 \times 3)+(75 \times 1)}{4}=93.75
$$

Since the credit is $95 \%$ of the average base period net income, it is, in this case, $89.061 / 4 \%$ of the average of the income of the three highest years (disregarding subsequent changes in invested capital).

10 Treas. DePT., BulL., Sept. 1942, at 71.

${ }^{17}$ It is the present writer's impression that examples are to be found in $\$ 116(d), 2 d$ par., and $\$ 120$ of the Internal Revenue Code. 
one taxpayer and utilized by no other taxpayer since then. Section $722(b)(4)$ offers one of the more striking examples: “... any acquisition before May 3I, I94I, from a competitor engaged in the dissemination of information through the public press, of substantially all the assets of such competitor employed in such business with the result that competition between the taxpayer and the competitor existing before January I, I940, was eliminated, shall be deemed to be a change on December 3I, I939, in the character of the business. ..." Without passing on the merits of this particular case, and while agreeing that one-taxpayer clauses cannot be dispensed with entirely, it may be asked whether taxpayers should not be prepared to accept a certain amount of lottery element in a tax law and put up occasionally with a certain amount of inequity, for the sake of keeping the law from disintegrating into a case book. But if taxpayers are to accept this rule of the game, they in turn have grounds for demanding that the tax rate be kept a considerable distance below 100\%. Asking the taxpayer to take a chance on being treated somewhat less favorably than a competitor is reasonable, but asking him to gamble his business life is not. A tax rate of $90 \%$ or $100 \%$ on a base so complex as that of the excess profits tax will almost surely ruin some taxpayers, if special relief is not provided either by administrative discretion or in the law. The present excess profits tax law, by employing a high rate on a narrowly defined base instead of a lower rate on a more broadly defined concept of excess profits, makes a substantial amount of detailed relief inevitable.

These remarks do not imply that the tax law should set no standards; if the legislators cannot devise generally applicable tests, it is unreasonable to expect the administrators or the courts to do so. The renegotiation statute, ${ }^{18}$ by making no attempt at all to define "excessive profits," opened the path for treating each case as a special instance far more widely than does the Revenue Act of 1942 . The point is, rather, that while the tax law can never be simple in the sense of failing to define standards, the number of sets of standards might be considerably less than in the present law.

In any event, and whatever one's preferences, all future students of the theory and technique of excess profits taxation will owe a debt of scholarly gratitude to the Treasury officials and Congressional committee members of $1940-42$ for having explored the dark recesses of the base-period concept more deeply than any had dared to do before them.

General Standards under the Base-Period Concept.-Further evidence of the importance that Congress attaches to the base-period technique is the care that has been devoted to refining the general concept of base-period income. Here it is a question not of substituting hypothetical for actual data, but of adding, subtracting, or combining in various ways the entries that appear in the records of the taxpayer.

One class of adjustment allows the taxpayer to add back certain items that were deducted in the base-period years in computing net income for the ordinary income tax, or requires him to subtract certain items that he was not allowed to subtract (or failed to subtract) for income tax purposes. The general question then arises: shall

\footnotetext{
${ }^{18}$ Act of April 28, 1942, Pub. L. No. 528, 77th Cong., 2d Sess. $\$ 403$.
} 
analogous adjustments be required (or permitted) in the income of the taxable year? Long-term capital gains and losses, income from retirement or discharge of bonds, etc., and dividends from domestic corporations are not taken into account in computing the base-period income, and they are correspondingly ignored in computing the income of the taxable year. But there are several instances where such correspondence is not maintained; the adjustment is made, to the benefit of the taxpayer, in the base period, but he is not required to make an analogous adjustment in the taxable year. Examples are losses and expenses on the retirement or discharge of bonds, etc., and casualty, demolition, and similar losses. And a catch-all subsection (Sec. $\operatorname{lrI}(\mathrm{b})(\mathrm{I})(\mathrm{J})$ ) permits the adding back of "abnormal" deductions.

One of the tests employed is whether the base-period deductions (of a given "class") exceeded by more than $25 \%$ the average amount of deductions of the same class for the four previous taxable years. Thus a secondary base period is created, by which the primary one is tested; the secondary base period may extend back as far as 1932. This is probably the only instance in the history of excess profits taxation of a compound base period.

That a base-period income averaged over a short term of years should be purified to some extent of rarely occurring items like expenses of debt retirement or casualty loss is understandable. But should the purification in the base period be complete? Over the long term, those expenses do occur, although not perhaps to the extent that a completely unpurified four-year average of 1936 - 1939 experience would indicate. If the excess profits tax is not designed to last over a long term, however, the argument for complete elimination of the expense in the base period becomes stronger. ${ }^{19}$

Another class of adjustment provides a base-period history for a corporation that was not, in its legal self, in existence before 1940 , but that has an unbroken business history extending back through one or more predecessor corporations, or even unincorporated concerns. The revision, in I942, of the already highly elaborated Supple ment $A$ is again evidence that Congress considers the primary test for excess profits to be base-period experience, not a percentage return on invested capital.

The Invested-Capital Method.-The invested-capital method plays a dual role in the excess profits tax law: in some cases it supplements, and in others it replaces the base-period method.

As time passes and a concern expands or partially liquidates, its base-period experience, even when refined and reconstructed with the exercise of the most powerful imagination and ingenuity, becomes less satisfactory. Hence the provision allowing the addition, to the average base-period net income, of $8 \%$ of the net additions to capital since the end of the base period, and requiring the subtraction of $6 \%$ of the

\footnotetext{
${ }^{10}$ Moreover, there may be some danger of exaggerating the importance of these provisions. Of the I6,586 returns filed under the income method for calendar I94I and for fiscal and part years beginning in, and the greater part of whose accounting period fell in, r94I, "the number with abnormal deductions in the base period is r,282"-not quite 8\%. TRfas. Deprt., Bull., Sept. 1942, p. 71. This is a mucb smaller percentage than the present writer had expected.
} 
net capital reduction. Expanding concerns will thus, in time, be restricted to a return approaching $8 \%$ on their total invested capital, although they may have had base period earnings at a much higher rate on the amount of capital then invested. And shrinking firms will be allowed higher and higher percentage returns on what is left of their capital-a privilege that will probably be immaterial, or the concern would not be shrinking. But this section of the law (Sec. 7r3 (g)), although carefully worked out as far as it goes, does not allow the inclusion of borrowed capital, and provides only a flat rate of return; it therefore gives the impression that it is not expected to play a very important role.

As an alternative to the base-period method, the invested-capital method requires an estimate of the total amount of invested capital as of a certain date. The present law follows the (United States) precedent of the First World War in avoiding a current valuation of the assets actually in use in the business, and measuring instead the money and other property paid in to the corporation, plus earnings and profits accumulated subsequently. With some exceptions, appreciation in the value of assets -due, for instance, to the development of a quasi-monopoly position-is therefore not counted as a part of invested capital so long as it is unrealized and hence has not appeared in earnings and profits. The consequent impairment of vested property rights implicit in this refusal to take unrealized appreciation into account has been avoided by making the use of the invested capital method optional with the corporation, which can therefore rely on a rich base-period experience to free it from excess prcfits tax. The current profit may be $20 \%$, or $100 \%$, or any other per cent, of invested capital, without becoming subject to the excess profits tax, so long as it does not exceed the rate of return implicit in the actual or constructive base-period figure (and assuming no appreciable net addition to capital since 1939). Congress strenuously resisted the Treasury's efforts to turn the option in favor of the Government, as under the Igr8 law. Evidently the protection of the current value of corporate shares was considered by Congress to be very important.

Giving the option to the taxpayer also protects corporations whose base-period experience has been so poor that no amount of "reconstruction" can get them a credit equal to more than a very low return on paid-in capital, surplus, and accumulated earnings and profits.

From the technical point of view, the chief features of interest in the present law's concept of invested capital are: (I) the tracing of the corporation's history back through tax-free reorganizations; (2) the use of basis (unadjusted) where property was paid in for stock, thus avoiding, with some exceptions, a new, direct valuation of the property as of that time, in cases where the value of the stock itself was not readily ascertainable; (3) the use of basis (adjusted) for determining the ratio of inadmissible assets to total assets; (4) the inclusion of part of borrowed capital; and (5) the refusal to limit the inclusion of intangibles. The first three will not be discussed here, since they do not represent a fundamental change in concept, although the use of basis is an important technical step in avoiding troublesome valuations. 
Not even a summary of the issues involved in borrowed capital can be attempted here. But it may be observed that the present law gives them only a partial test.

In the first place, the law includes in invested capital only one half the borrowed capital, after excluding entirely all borrowings not evidenced by certain formal written instruments. This fraction represents a compromise between ( $I$ ) the fear of hardship that exclusion of borrowed capital would cause, especially to young, growing corporations that must borrow heavily to take advantage of opportunities before they vanish, and (2) the fear that unlimited inclusion of borrowed capital would be abused by unnecessary borrowing on the part of strong corporations that could get loans at rates of interest so low that there would be a gain from the transaction even if the borrower could find no use at all for the money. It is virtually certain, however, that if the same amount of time had been devoted to strengthening the investedcapital concept as has been devoted to the base-period measure, a way would have been found to obviate such abuse, while retaining the advantages desired, and thus permitting the full inclusion of borrowed capital.

In the second place, the rate of return allowed on invested capital is set so low $(5 \%$ to $8 \%$ ) that in a few instances it is probably exceeded by the interest rate at which the taxpayer is borrowing. In these cases, the taxpayer would be better off if borrowed capital were excluded entirely and he were consequently allowed a full deduction, in computing excess profits net income, of interest paid, instead of being restricted to deducting half of the interest as at present.

The existing law makes no attempt to pioneer by including leased capital in invested capital. Instead-evidence again of the strong preference for the base-period approach-it apparently allows for the construction of an imaginary base-period income, for corporations not in existence before January $r$, r940, as shown by this illustration: ". . . a corporation . . . commenced business in r $94 \mathrm{x}$ with a leased plant valued at $\$ 1,000,000$, but with invested capital paid in of only $\$ 40,000$. Since the invested capital of such company is unusually low relative to the size of its operations, it would be subject to an unreasonable tax burden if required to compute its excess profits tax under the invested capital method. It would therefore be given constructive average base period net income and would be entitled to compute its credit on the average earnings method."20

The legitimacy of an intangible asset as a component of invested capital is fully recognized, in contrast to the excess profits tax law of the last war. And here again the predominance of the base-period approach is apparent. When the intangible has failed to get on to the taxpayer's books (technically, when it has no tax basis), as when it has arisen from outlays that have been charged off to expense, the inaccuracy is corrected, not necessarily by a revamping of the expense and capital accounts, but by building up a hypothetical (constructive) base period income:

"For example, a corporation, which was of a class requiring little invested capital but necessitating the establishment of contacts with the trade which it was its business to sup-

${ }^{20}$ SEN. Rep. No. I63I, stipra note 3, at 203-204. 
ply, commenced business early in 1940. It lost money during its first 2 years of operations but by 1942 began to realize sizable profits. This company would be eligible to receive a constructive average base period net income on the grounds that one of its principal assets, the goodwill of its clientele, was not reflected in invested capital."21

Among the disadvantages of computing invested capital through the liabilities side of the balance sheet, instead of segregating out the assets actively used in the business and valuing them currently, there are several important ones that the present law does not remove. This is understandable so long as the invested-capital method is regarded as a sort of general relief provision for a short-lived tax based primarily on the income-credit method, for these disadvantages will probably not be serious during another two or three years of war.

One of them is the inducement offered to arrange a transfer of corporate ownership of the assets of a prosperous business with an earning power well above the taxfree return allowed on the corporation's invested-capital figure. If the sale of the assets, from one corporation to another, can be so arranged that it does not fall into the "tax-free" category, and if the hitherto unrealized appreciation in value of the assets, now realized by the sale, can be made to appear in the form of gains on "capital assets," the year's ordinary corporation tax is increased, but the excess profits tax is decreased for the current year and all future years: the net long-term capital gain realized upon the sale of the assets (in excess of the year's net short-term capital loss) is taxable under the ordinary corporate income tax at a maximum rate of $25 \%$; but a new, high invested capital figure is created that will serve to exempt much or all of future income from the excess profits tax. So long as the tax is believed to be temporary, however, there is probably little danger of such tax-induced sales.

Conversely, if a corporation has sustained an unrealized loss in the value of its assets, any transfer of the assets, not under a "tax-free" exchange, will cause the loss to be realized and will in general make the assets worth less for excess profits tax purposes. Indeed, a similar deterrent to transfer exists even when the loss in value of assets has been realized, that is, has been reflected by the accumulation of a deficit in the earnings and profits account. The law does not require that such a deficit be deducted from the original capital and surplus paid in, in computing invested capital. But, with some exceptions, as soon as the assets are transferred to another corporation, whether or not under a "tax-free" exchange, the accumulated deficit becomes realized, in fact or in effect, in the computation of the invested capital of the transferee corporation. A corporation with assets having a present worth and an adjusted basis of \$ro million, and outstanding stock of $\$ 25$ million and an accumulated deficit of \$15 million, can reckon its invested capital at $\$ 25$ million; exceptions aside, if the assets are transferred to another corporation, old or new, they give rise to only \$ro million of invested capital. There has been some evidence that the benefit accruing from holding on to a book deficit has impeded important reorganizations.

The present law does a little cautious pioneering in allowing for differences in

${ }^{21} 1 d$. at 203. 
risk. It does not explicitly refer to such differences, but they were the chief consideration in the enactment of the borrowed capital provision (a given amount of total investment is much more of a gamble at great odds by the equity owners if a large part of the investment is borrowed capital) and in the graduation of the permitted rate of return on investment, which now varies from $8 \%$ on the first $\$ 5$ million of invested capital to $5 \%$ on the excess over $\$ 200$ million. Graduation of this kind is a recognition of the tendency of risks to cancel out in large numbers; a small company drilling one oil well a year, for example, obviously faces more risk than a large one drilling many hundred. Mere size, other things being equal, itself lessens risk.

The Scope of the Tax.-The present law seems to reflect a desire to tax primarily, or even exclusively, excess profits derived from the employment of business capital in the corporate form. But the exclusion of profits derived chiefly from personal service reflects more a deliberate aim, a freely chosen limitation on the concept, than does the exclusion of all unincorporated enterprises, which was dictated by fear of administrative difficulties. If Congress could have been shown some easy way of isolating excess profits on capital employed in unincorporated enterprises, it would very likely not have restricted the tax to corporations. At least, it may be presumed that Congress did not aim at promoting disincorporation, which appears to have reached significant proportions in some industries, owing to the excess profits tax and the corporation tax. (The writer has the impression that this is the case with the women's garment manufacturing industry, for example). The exclusion of profits derived primarily from personal service, on the other hand, seems less forced by circumstances than by doubt over the soundness of a concept of "excess" personal-service income. Still, if that were so, why did not Congress grant outright exemption to those corporations "of a class in which capital is not an important income-producing factor" (Sec. 722 (c) (2)), like a corporation doing business as fashion consultants, employing a large technical and professional staff? Incidentally, in these cases, it becomes imperative to resort to a constructive base period income, if the corporation was not in existence before January I, I940. Both intent and execution remain somewhat unclear in this personal-service area of the "excess" concept.

Elimination of the One-Year Accounting Period.-"Elimination" is too strong a word to apply literally with respect to what has happened to the one-year accounting period under the income tax and the excess profits tax, but it is scarcely too strong if taken in the sense of end results over a period of years. In recent revenue acts, breaches have occurred at widely separated points in the barriers, necessarily somewhat artificial, that mark one year's income off from the next. The speed with which last-in first-out inventory accounting has gained favor for tax purposes is an illustration; the revival of the two-year carry-forward ("carry-over") of losses in the Revenue Act of 1939 is another. But it remained for the Revenue Act of 1942 to effect what will probably turn out to have been the most important change of this kind in any federal revenue law, by adding a two-year carry-back to the two-year carry-forward 
and making it applicable not only to operating losses but also to unused excess profits tax credits. In effect, something approaching a five-year moving average has been introduced. There are probably better averaging methods available, but proponents of averaging will not be inclined to complain, in view of the size of this one stepif it really is a firm step. To mean much, the carry-back provision must be kept in force, even though the rest of the excess-profits tax is repealed, for some time after the war; and Congress and the public must be ready to accept the necessity of substantial refunds to corporations, including very large ones that will not be in financial distress, however good their claim may be on grounds of equity.

The net income derived from gross income of any given class, for the taxable year, may be decreased, for excess profits tax purposes, to the extent that it is "abnormal" either in nature or amount and can also be shown to be attributable to other years. Abnormality in amount is defined as being more than $25 \%$ higher than the average for the four previous taxable years. Consequently, any class of gross income that has been increasing for four years at an annual rate (compounded) of more than about I0\% is "abnormal." But the Regulations make it clear that fluctuations due merely to changes in prices, costs, demand or competition do not make the abnormal income attributable to other years.

The net abnormal income gives rise to excess profits tax for the past or future years to which it is found attributable, except that if it falls in 1939 or an earlier year it has no effect at all, not even in the measurement of base-period income. Net abnormal income thrown into a future year cannot give rise to an added tax in such a year greater than the tax saved in the present year (minus the increase caused by this provision in intervening years). Hence the taxpayer cannot lose, by this averaging provision, no matter what happens to tax rates.

There may still be a practical problem of tax payment if the taxpayer is not provident. When the future year arrives, he will have to pay perhaps $90 \%$ of a substantial amount that he received, not in that year, but some years before. It will be interesting to observe whether this difficulty, considered by some to be a decisive objection to the moving-average type of income-averaging, proves important in practice. Surprisingly enough, the data for the 32,976 returns filed for 194I (to July 3I, 1942) indicate very little use of this relief for "abnormalities" of the taxable year: "The number of returns with abnormal income attributable to other years is ${ }_{528 .}{ }^{\prime 22}$ In any event, the construction of and experience with this elaborate averaging device may easily have significant implications for post-war income tax legislation despite its intended inapplicability to profit fluctuations associated with the business cycle.

Income Tax and Excess Profits Tax.-The extraordinary increase in the yield of the excess profits tax on $194 \mathrm{I}$ and subsequent incomes over that on 1940 incomes ${ }^{23}$ is due in large part to the fact that in I 940 the normal tax and surtax were computed

\footnotetext{
22 Treas. Dept., Bull., Sept. 1942, p. 71. The returas "filed for I94I" here include only those for fiscal and part years beginning in, and the greater part of whose accounting period fell in, I94r.

${ }^{23}$ Fiscal I941: \$164 million; fiscal 1942, \$1.6 billion; fiscal 1943, estimated, \$5.7 billion; fiscal 1944, estimated, \$ro.3 billion. Budget ... for ... Fiscal ... 1943, p. A-3; Budget... for ... Fiscal r944, p. A-1.
} 
first, and deducted from net income in computing the base of the excess profits tax, while in I94I the excess profits tax (in I942, the excess profits credit) was computed first and the normal tax and surtax were then applied only to the remainder. The change was motivated chiefly by a desire for the increased revenues it would bring, under a given set of rates, and did not reflect any fundamental change of mind concerning the proper concept, aside from the consideration advanced by the Ways and Means Committee that "It seems unfair to allow that part of the income tax which is computed on income which is not subject to the excess profits tax to reduce the excess-profits net income."24 But the I940 method itself did not reflect any profound convictions on concept. If the normal tax and surtax are assumed to be non-shiftable and are designed to give the Government a stated share in the corporation's standard, fair, or peacetime reward, the present system is logical. Moreover, as the excess profits tax rate approaches $100 \%$, the I940 system blurs the distinction between excess profits tax and normal and surtaxes; with a 100\% excess profits tax rate and the normal and surtaxes deducted in computing the excess profits base, a decrease in the normal and surtaxes would bring the taxpayer no gain and an increase, no burden. Under the present system, a variation in the normal or surtax rates has a real meaning for the corporation, regardless of the excess profits tax rate. But, assuming a given set of normal tax, surtax, and excess profits tax rates, the present system leaves the corporation with large excess profits better off than the corporation with small excess profits, compared with their relative situation under the I940 law. Under that law, as total profits increased (once the corporation had already passed into the excess profits zone), the normal tax and surtax took part of the increase and the excess profits tax took part of the rest of the increase. Now, the only thing that happens is that the excess profits tax takes part of the increase. In other words, under a given set of rates, the present system imposes a lower combined marginal rate (even disregarding the $80 \%$ limitation).

The change in I94I tended to make the base-period alternative less attractive, since base-period income taxes were imposed at lower rates than the wartime normal tax and surtax, but there is no indication that the change was made deliberately to increase the relative importance of the invested-capital method.

Summary. The concept of excess profits in the present law, partly explicit and partly implicit, seems to be something like this: excess profits are the excess of the average annual profits of a business corporation during the years 1940 -x 9 - over $89 \%$ of the annual average profits that would have been realized in the three best years of the period 1936 -I 939 (or $95 \%$ of the four-year average) by the corporation in question if its reasonably assured potentialities, as of January I, I940, had been allowed full expression during that time, free of rarely occurring unfortunate episodes, physical or economic, and if the general business background had been happy enough to permit a return of at least $5 \%$ to $8 \%$ on the capital put into the business, including half the borrowed capital.

${ }^{24}$ The Revenue Bill of 194I, H. R. REP. No. 1040, 77th Cong., 2d Sess. (194I) 24. 
This definition, long and awkward though it is, obviously slurs over or omits considerations that would be important if the tax were to have a long life ahead of it. But there seems to be little tendency anywhere to assume that it will. For one thing, as the analysis above has indicated, the workmanship that has been lavished on the law and regulations has been concentrated on the features that are more significant for a temporary tax that carries a very high rate. And this kind of effort, requiring as it does a continual straining to provide for a hundred and one special cases where the tax rate might otherwise prove destructive, has been so exhausting to the research staffs, the bill drafters, the Congressional committees, and the taxpayers and their representatives that the repeal of the excess profits tax could, on the whole, bring as its immediate reaction only a sense of relief. Under a much lower rate, with effort devoted to refining the standards that would be applicable over a long period of time, an excess profits tax might conceivably become a permanent part of the federal revenue system. But this is not the kind of tax that Congress wanted for war, and there is as yet no indication that Congress wants it for peace. 